UDC 811:111:656.61(09) (045)

DOI https://doi.org/10.26661/2414-1135-2020-80-2-13

\title{
ORIGIN AND ETYMOLOGY OF MARINE SUPERSTITIONS
}

\author{
Nikulina O. L. \\ Candidate of Philological Sciences, Associate Professor, \\ Head of the English Department \\ National University "Odessa Maritime Academy" \\ Didrichson str., 8, Odessa, Ukraine \\ orcid. org/0000-0001-5206-5998 \\ elnikulina55@gmail.com
}

Key words: cultural awareness, taboo, omen, symbol, sign, talisman, custom, tradition, etymology, marine superstitions.
Nowadays intercultural awareness and cooperation of people working together that have different cultural background is highly spread and very effective. It is of utmost importance and relevance to those who work in international teams, a good example of such a team is a ship's crew in a multinational or mixed crew. While working together in one crew on board one ship people have to communicate and solve professional problems 24 hours a day. For successful communication they not only have to know the universal language, English, which is adopted as maritime language worldwide, they also have to be in the know of customs and traditions, symbols and signs, taboos and omens related to different countries and cultures, which is essential at sea, to escape possible psychological misunderstanding and even collisions while achieving their common target. That is why we decided to concentrate our research on the origin and etymology of marine superstitions.

The history of marine superstitions dates back to the very first days of seafaring. At the time when the first ships appeared and the first voyages started to be organized, the mariners didn't have any maps or navigational aids, they relied mostly on their intuition. The seamen of those times wanted to prove that the Earth is round, which explains the fact that great Columbus sailed west to reach the coasts of India while in reality he reached the coasts of America, that's why the locals are still called Indians. The existence of this continent the Europeans were not aware of. Needless to say that such long expeditions required not only a solid stock of food and water on board but also psychological support for the people in the open ocean that could not communicate with their relatives and families, the mariners were restricted to the company of only their crew fellows. The big helper in this situation were believes. That is how the marine superstitions began to appear. They still exist on board every ship until now, but not all the seamen can explain them.

That is why the aim of this paper is to investigate and systematize the terms and phrases reflecting marine superstitions according to their functions and attribution to the notions that they suggest: people, animals, objects, traditions. This is the first attempt of such classification made in the domain of maritime English not only in Ukraine. The methods used were mostly historical comparative and contemporary comparative. The suggested paper will hopefully trigger the interest not only of the seafarers and people related to the maritime business, but also to all those interested in etymology of marine/nautical ESP. 


\title{
ПОХОДЖЕННЯ ТА ЕТИМОЛОГІЯ МОРСЬКИХ ЗАБОБОНІВ
}

\author{
Нікуліна О. Л. \\ кандидат філологічних наук, доиент, \\ завідувач кафедри англійської мови \\ Національний університет «Одеська морська академія» \\ вул. Дідріхсона, 8, Одеса, Україна \\ orcid. org/0000-0001-5206-5998 \\ elnikulina55@gmail.com
}

\begin{abstract}
Ключові слова: культурна свідомість, табу, прикмети, символи, знаки, талісмани, звички, традиції, етимологія, морські забобони.
\end{abstract}

Нині міжкультурна свідомість та співпраця людей з різним культурним походженням дуже поширена та ефективна. Це дуже важливо та релевантне для тих, хто працює в міжнародних командах, яскравий приклад являє багатонаціональний чи змішаний екіпаж судна. Працюючи разом в одній команді на одному судні, люди мають спілкуватися та вирішувати професіональні задачі 24 години на добу. Для успішного спілкування вони мають знати не тільки універсальну мову, англійську, що іiі було прийнято як морську мову у всьому світі, вони також мають знати звички та традиції, символи та знаки, табу та прикмети різних країн та культур, що пов’язані з морем, щоб запобігти можливого психологічного непорозуміння, навіть конфліктів у процесі досягнення спільної мети. Тому ми вирішили націлити своє дослідження на походження та етимологію морських забобонів.

Історія морських забобонів сягає початку морського судноплавства. У час появи перших суден та організації перших перевезень у моряків не було морських мап чи навігаційного обладнання, то вони сподівались лише на свою інтуїцію. Судноплавці того часу хотіли довести, що Земля кругла, про що свідчить той факт, що великий Колумб прямував на захід, щоб досягти Індії, але реально досяг Америки, і тепер місцеві звуться індіанцями. Про існування цього континенту європейці не знали. Даремно казати, що такі виснажливі експедиції вимагали не тільки запасів їжі та води, а й психологічної підтримки для людей у відкритому океані, котрі не могли спілкуватися з рідними та сім'€ю, бо вони були обмежені тільки компанією своєї команди. Великим помічником у цій ситуації було вірування. Так народжувалися морські забобони. Вони існують на суднах і сьогодні, але не всі моряки можуть їх пояснити.

Ось чому мета цієї статті - дослідити та систематизувати терміни та фразеологічні вислови, що відображують морські забобони відповідно до їх функцій та належності до різних національних властивостей: люди, звіри, об’єкти, традиції. Це - перша спроба подібної класифікації в полі морської англійської мови. Методи, що були застосовані, - переважно історично порівняльний та сучасний порівняльний. Пропонуємо увазі читача дослідження, що, сподіваємось, викличе інтерес не тільки у людей, пов'язаних з морською спеціальністю, а і у всіх, хто цікавиться етимологією морської англійської мови.
Introduction. The marine business is developing very fast nowadays with lots of new types of ships being built and new routes being created. Since maritime business is international, many crews nowadays are multicultural and professional maritime English is spoken on board. The problem of cultural awareness in mixed crews is vital in solving professional situations, problematic at times. The social world that seafarers envisage on board their ships is different from the social world of those people who live on shore. Seaman live in an enclosed location, a ship, which is surrounded by water and cut off land, which is not natural for human species. That's why the seamen are followed by the drastic desire to come back to where they belong, i.e. home, to their families. Of course, the navigation now is safe, people live in comfortable conditions on board, but that was not always so. Historically all seamen were superstitious. So we 
thought that tracing back the origin and etymology of marine terms and phrases connected with marine superstitions would be of high interest and relevance. We followed the two track idea of our research: first we systematized the observed bulk of lexical material according to the positive/negative function of the terms and phrases, and secondly, we attributed the terms according to the notions they reflect: people, animals, objects, traditions.

Positive and negative connotations of superstitions. In the following article we undertook an attempt to systematize marine superstitions according to two criteria: a) terms/phrases with positive or negative connotation and $b$ ) groups of notions that marine superstitions refer to.

The word superstition is defined as "the belief that particular events happen in a way that cannot be explained by reason or science; that particular events bring good or bad luck" [2, p.1485]. Linguists include in the subject of "superstitions" such things as divinations, spells, cures, charms, signs, rituals and taboos. While divinations or fortune telling, signs and rituals can be interpreted as with both good or bad connotation, cures and charms definitely speak about protection or good luck, while spells and taboos suggest the idea of ill luck [1, p. 3].

Superstitions appeared in the beginning of human civilization formation when primitive pagan people feared that their livelihood could be harmed or even destroyed by evil forces of nature, which they couldn't explain and people deeply believed that tragic events may be prevented by some rituals, signs etc. Seamen are a very special type of people because of their profession peculiarities: they are isolated from the society on a spatially restricted territory - a ship, and their life is exposed to severe dangers of unpredictable sea; in other words, their lives are in a much bigger danger than of those who live on land. Needless to say that they with years have developed their own world of various superstitions, charms, signs, taboos, etc. which they stick to up till now.

In this article, we made an attempt to analyze the most frequently followed superstitions from the point of view of being interpreted as "positive" and "negative", that is bringing good or bad luck. Marine superstitions are frequently addressed to not only by seafarers, but also by people living on land because seamen share this information with their family members after the voyage. We also tried to make a comparative analysis of superstitions naming in different countries.

Some people even don't know the origin of a superstition as that of the marine one, but are well aware of the meaning of it and use such expressions in everyday life. For example, all people love travelling nowadays and can afford it. No doubt the tourists have a habit of tossing a coin in the waters of a Rome or Paris fountain so that they may come back and visit the place again. That's a notorious fact, but not many people know that this sign for good luck comes from marine superstitions. The custom was registered in the 20-ies of the 20th century when fishermen, when the nets are being paid out, cut the slice in one of the pieces of cork attached to them and insert a coin, by way of informing Neptune that they are prepared to pay for the fish they catch. Whenever a new fishing boat is launched, a coin is placed and kept permanently under the mast for good luck [1, p. 92]. A coin thrown into the sea was also a kind of omen, pleading for the wind to come in the epoch of tall ships when the sailing completely depended on the wind to blow the sails. After whistling and blowing didn't help the sailors would use their last resource, they threw a sixpence overboard, believing this enchantment would help. They also accompanied the ritual with the wordings: "Blow a little breeze, please, Father", meaning of course Father Neptune [1, p. 446].

Another example of a very common sign of good luck is horseshoe. It is usually placed above the front door for luck, and the forks should look upward, not downward, otherwise the horseshoe, being a symbol of a cornucopia or horn of plenty will turn to look like a topsy-turvy vase that cannot keep anything inside. The origin of this superstition also roots in marine tradition. In the $19^{\text {th }}$ century it was usual to nail a horseshoe on the foremast of merchant vessels which was meant to keep witches and wizards from hindering the voyage or damaging the ship. Since then practically no vessels have put to sea without this talisman. Admiral Nelson had a horseshoe nailed to the mast of the Victory [1, p. 204].

One more association that would definitely ring the bell for many people is connected with the word "cat". In ancient Egypt cats were worshipped as sacred animals. In medieval times a cat was a sym$\mathrm{bol} / \mathrm{sign}$ of witch. It is interesting to trace how in different cultures different color of cats meant diametrically opposite thing. Slavs would associate black cat with bad luck, and when black cat crosses the road in front of you it's better to use another itinerary. In Britain black cat was considered a lucky talisman, lucky to possess and to touch; the blood of a black cat was believed to cure diseases while white cats in this country bring ill luck to the house and people prefer to get rid of them. As marine tradition goes cats were also treated differently in different times. In the epoch of sailing vessels, the superstition was that drowning a cat was the surest way of raising a favorable wind while in the $19^{\text {th }}$ century the common sailors would account it very unlucky to throw a cat overboard or drown one at sea. As we can see sometimes superstitions can be very contradictory.

The expression "there's no room to swing a cat" is quite popular and often used on land meaning "confined, restricted space too small for a particular purpose" [3, p. 34]. But who would imagine a situation when people could swing a cat on land? The origin of this expression comes from nautical slang and dates back to the times when sailors were often punished for disobedience by "cat-o'-nine-tails" which was a slang expression for nine-lashed whip. 
The punishment was administered on deck, generally in the space between the poop and the main mast which was a pretty small area and to swing the cat effectively required quite some skill from the boatswain to execute the punishment.

Human nature tends to balance the good and evil signs that the Universe always suggests, so the human attitude to good and evil is reflected in peoples' believes and their reflection in the language. Alongside with symbols/signs associated with good luck we'll find many words and expressions associated with ill luck which originated within the frame of marine English.

One such example of bad luck is the presence of a dead body on board ship. It was considered that a corpse defiled ship, so the sailors would do everything possible to get rid of a suddenly deceased seaman very often throwing the body overboard. After that the deck was thoroughly cleaned with water. By the way this tradition to wash the place the coffin stood was transmitted to houses on land - after the coffin had been brought out of the house and the funeral party had gone one of the servants washed the threshold [1, p. 97].

Another sign of ill luck was pins on ship. They were considered "spiteful witches and ought never to be brought on board a vessel" [1, p. 312]. On the contrary, there is diametrically opposite tradition ashore, which says that wearing a safe pin somewhere on an invisible side of your clothes will bring you protection from bad luck.

Notions and etymology of superstitions' subjects. As was mentioned above the most frequently kept marine superstitions will be considered here from the view of bringing good luck or bad luck. During the research we figured out several groups of marine superstitions connected with: 1. People. 2. Animals. 3. Objects. 4. Traditions.

1. People. In the history of seafaring definitely creation and development of marine superstitions were very important not only for mariners themselves, but also for people who waited for them ashore or just met them in their town streets. That's why some superstitions connected with mariners were created by people on land. We shall start with the word "sailor". When sailors came ashore the hands crowded round to touch them, because it was considered big luck. Especially important was to touch the sailor's color for girls and children. Bell-bottomed trousers, the robe and the collar around the neck - these were sure signs of sailors who brought good luck to people on shore. Sailors were well known to be the symbol of strength, courage and good luck [1, p. 335].

Another good sign for a ship was children on board ship. "Children are deemed lucky to a ship; their innocence being considered by sailors as protection and indicated successful voyage" $[1, \mathrm{p} .71]$.

The two examples above were the examples of people bringing good luck, but the question is: why according to some believes different people brought different luck? There were people that definitely were not wanted on a ship. Clergyman on ship was said to bring bad weather. Mariners thought that if clergymen were playing games with the devil on land being hypocritical and sinful, they would behave the same way at sea, so gentlemen of that kind were considered very unlucky to be on board.

Another unlucky person to be found on board ship was a woman. Today it is difficult to imagine any ship without a woman. Women are studying in Maritime Academies all over the world and they successfully cope with the work of cooks, waitresses, maidens, passenger administrators, engineers, radio officers, electricians; they can even manage with navigation responsibilities and be captains! But that was not always so. Women were considered ill luck for the ship and the crew because they were thought of potential temptation to the sailors. The old sea superstition was that woman on board is unlucky sign. A woman on board was also considered to cause a storm.

2. Animals. We would like to start with birds that accompany the ships in the ocean and they are seagulls and albatrosses. Seagulls are considered to be, strange as it may seem, a bad luck because they are associated with the stormy petrel. These birds are regarded as objects of superstitious fear and are believed to possess the supernatural agency in creating danger for the mariner. Seagulls were reported to cry before any disaster. Many seamen also think of seagulls as souls of the dead/departed sailors and if three seagulls flow overhead that maybe the sign of the coming death on board. You should never shoot a seagull.

Albatrosses are also sea birds, and superstitions connected with them are completely different to those of the seagulls because since ancient times mariners always believed that they were birds of good luck. Once a crew complained about a couple of albatrosses were taken to the zoo (they are big and beautiful birds) they had had a series of misfortunes.

Goat used to be hanged on the mast by Scottish seamen to procure favorable wind, which is definitely for good luck during the voyage. On the other hand, such animal as dead hare or rabbit on board is said to bring bad weather. It would have been very unlucky to go to sea with even a fragment of rabbit's hair anywhere on the boat. Stories are told all along the coast of Scotland that mischievous boys got hold of rabbit skins, filled them with rubbish and placed them in the sterns of boats, in order to stop the men from going to sea $[1$, p. 192]. This is definitely for bad luck.

3. Objects. Needless to say that the objects that surround us usually are very important for people. In the house everybody has his favorite place or small pieces like statuettes, or some souvenirs that we love to look at, rub in our hands and feel the reminiscences about the day when we bought them. The same goes with things and objects that we'd like to get rid of because of bad memories. This typically human nature works with mariners, that's why some objects they treat like good signs, some like bad. 
The first example will be figurehead, an omen of protection of the ship. They were the real carved figures, "usually human (but also very often animals), fixed on the stem high in the bow $\langle\ldots>$ written as two words, "figure head" [3, p. 49]. The prime function of such figures was a distinctive one: along with ship's tonnage, dimensions, port of registry, etc. the classification societies such as Lloyd' and Bureau Veritas used to also mention the type of ship's figurehead. Later their function tended to be more a decorative emblem. "Its origin is probably both religious and personal, in a milieu where a ship was treated as a living thing" $[3$, p. 50]. Gradually the female figure heads were predominant, especially naked or half naked, despite the fact that seamen considered women an unlucky sign. The point is that all sea gods were supposed to be males so the look of a beautiful woman would pacify them and avert the ship from storm.

Another object which is connected with marine superstitions is the knife. In the $19^{\text {th }}$ century it was said that it was a common practice among fishermen to stick the blades of the knives into the mast to bring the luck up. They used to say that "when the wind fails, you should stick a knife in the mast and a breeze will come" $[1$, p. 218]. So this was considered to be good luck.

4. Traditions. Traditions usually are referred to as "customs and beliefs existing among a particular group of people for a long time" [2, p. 1569]. They may also refer to rituals, to the perception of what is a good sign or a bad sign on board ship, what may or may not bring protection to the ship. Beginning voyage on Friday is definitely a bad sign. "A voyage that began on Friday is sure to be an unfortunate one". A Friday's sail, always fail [1, p. 168]. When Friday falls on the $13^{\text {th }}$ of the month it's a double taboo to set on sail. On the contrary, going to sea on Sunday is absolutely safe and is considered to bring the ship and seamen good luck. For mariners Sunday was always the most fortunate day. "Whatever voyage is begun on that day is sure to be prosperous" [1, p. 382].

Another tradition is to keep brooms and buckets always on board because losing broom or bucket at sea is considered very unlucky. That's because a broom or a mop is a tool of sweeping away all the "evil" like dust and dirt from the ship and a bucket is a vessel for keeping "good luck" like water, etc. "When a sailor lets a pail fall overboard, he feels "uncomfortable" < .. > because "a bucket lost overboard means ill luck" [1, p. 46].

Putting keys on the table. This is considered to be a bad luck because it means that the person who put keys on the table may lose all his money in one day. Compare with dropping keys meaning "a sign of a removal" [1, p. 216], some of the same idea traditions were mentioned above in this article, like tossing $a$ coin overboard for luck, touching a sailor, whistling for wind, etc.

Some of the traditions were originally connected not directly with the sea and sailors but with the mariners' family, their wives in particular. Seamen's wives used to practice some activities to avert the spell from their husbands when the latter were at sea. Later on these "safety keeping" traditions were transported on board ships by the seamen. For example, combing hair after sunset was considered to bring bad luck for those at sea, so fisherman's wife would never dear to brush her hair after midnight [1, p. 185].

Another tradition was: never wash clothes on the day of sailing. The seaman' wife would never wash on the day of the ship's set sail "because the rushing away of the washday water might wash his ship away" [1, p. 425].

Conclusions. The large domain of etymological bulk of the English language such as the origin of marine superstitions terms and phrases has been sparsely researched so far if at all. But this layer of lexicological material presents a great interest from historical and cultural viewpoint, although being vague and obscure. With this research we start lifting the veil off this mysterious but yet essential and live sector of the nautical language.

In the article marine superstitions were systematized according to:

a) having positive (e.g. horseshoe; tossing a coin overboard) and negative (e.g. woman on board; keys on the desk) connotation;

b) groups of notions they refer to: people, animals, objects, traditions.

The article may be of interest not only to students learning English etymology, but also for all the seafarers and people who deal with maritime business.

\section{BIBLIOGRAPHY}

1. Opie I. \& Tatem M. Dictionary of Superstitions. Oxford, New York : Oxford University Press, 1996.

2. Hornby A.S. Oxford Advanced Learner's Dictionary of Current English. Oxford University Press, 2005.

3. Jeans P.D. An Ocean of Words. A Dictionary of Nautical Words and Phrases. Carol Publishing Group, Toronto, Ontario, 1998. 180 p

4. Beavis B. \& McGloskey R.G. Salty Dog Talk. The Nautical Origin of Everyday Expressions. Sheridan House, London: New York : Granada, 1983. $96 \mathrm{p}$.

\section{REFERENCES}

1. Opie I.\& Tatem M. (199). Dictionary of Superstitions. Oxford, New York: Oxford University Press.

2. Hornby A.S. (2005). Oxford Advanced Learner's Dictionary of Current English. Oxford University Press.

3. Jeans P.D. (1998). An Ocean of Words. A Dictionary of Nautical Words and Phrases. Carol Publishing Group, Toronto, Ontario. 180 p.

4. Beavis B. \& McGloskey R.G. (1983). Salty Dog Talk. The Nautical Origin of Everyday Expressions. Sheridan House, London: New York : Granada, 96 p. 